\title{
Technological Transformation Processes and Resistance-On the Conflict Potential of 5G Using the Example of 5G Network Expansion in Germany
}

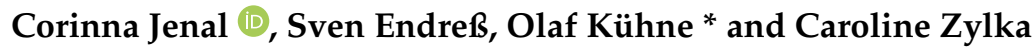

check for updates

Citation: Jenal, C.; Endreß, S.; Kühne, O.; Zylka, C. Technological

Transformation Processes and

Resistance-On the Conflict Potential

of $5 \mathrm{G}$ Using the Example of $5 \mathrm{G}$

Network Expansion in Germany.

Sustainability 2021, 13, 13550. https: / /

doi.org/10.3390/su132413550

Academic Editors:

Manuel Fernandez-Veiga and

Marc A. Rosen

Received: 5 October 2021

Accepted: 6 December 2021

Published: 7 December 2021

Publisher's Note: MDPI stays neutral with regard to jurisdictional claims in published maps and institutional affiliations.

Copyright: (c) 2021 by the authors. Licensee MDPI, Basel, Switzerland. This article is an open access article distributed under the terms and conditions of the Creative Commons Attribution (CC BY) license (https:/ / creativecommons.org/licenses/by/ $4.0 /)$.
Department of Geosciences, Urban and Regional Development, University of Tübingen, Rümelinstr. 19-23, 72070 Tübingen, Germany; corinna.jenal@uni-tuebingen.de (C.J.); sven.endress@uni-tuebingen.de (S.E.); carolinezylka@gmx.de (C.Z.)

* Correspondence: olaf.kuehne@uni-tuebingen.de; Tel.: +49-(0)7071-29-78937

Abstract: The expansion of fifth-generation wireless technology (5G) has been assigned the significance of a 'key technology' in connection with technological advances in the context of the digitalization of societies, which is a central goal of current governments in leading industrialized nations. As with other large-scale infrastructure projects such as the expansion of renewable energies as part of the energy transition in Germany, the plans for implementation are meeting with great resistance from the population, sometimes resulting in arson attacks on 5G transmission masts. Current research on $5 \mathrm{G}$ focuses primarily on technical-economic, health-related and, in the context of the COVID-19 pandemic, increasingly conspiracy-theoretical aspects, while questions of acceptance or conflict potential have received little attention to date. This article aims to address this research gap and, on the basis of a conflict-theoretical perspective according to Dahrendorf combined with a socio-economic contextualization in the sense of Bourdieu, approaches the question of the extent to which social conflict has already progressed and what regulatory possibilities socio-economic contexts assume in terms of significance. For this purpose, about 70 identifiable internet presences of citizens' initiatives against 5G were qualitatively and quantitatively evaluated.

Keywords: 5G; mobile communication; protest; citizens' initiatives; health; Dahrendorf; Bourdieu

\section{Introduction}

In the context of the increasing digitalization of societies, the expansion of fifthgeneration wireless technology (5G) is assigned the importance of a 'key technology' and 'main driver' for prosperity, security and competitiveness of national economies, so that the expansion of $5 \mathrm{G}$ is a central goal of the current governments of leading industrialized nations (cf., e.g., [1-5]). From the beginning of the introduction of 5G, a resistance of mobile phone opponents formed on a local to national level [6] and even attacks on 5G masts have been recorded in some cases [7-10].

The focus of our study is on the sociological question of which patterns of interpretation are presented by citizens' initiatives against the expansion of the $5 \mathrm{G}$ network. We also address the question of which spatial distributions of citizens' initiatives can be found in Germany, how this correlates with sociodemographic spatial distributions, and which social conflicts become apparent. Current research on 5G focuses primarily on technicaleconomic or health aspects of $5 \mathrm{G}$, while the processes related to the implementation of the energy transition as well as other large-scale infrastructure projects such as Stuttgart 21, the redesign of major parts of the railroad system in Stuttgart, including the construction of an underground through station instead of an overground terminus station, or the completion of the European North-South route through the new Brenner Base Tunnel and many more in Germany have already shown, that the introduction of large-scale infrastructure projects is also centrally linked to sociological questions such as acceptance. These issues are, 
however, dealt with rather marginally in current research on $5 \mathrm{G}$ and here in particular also in the context of conspiracy theories in connection with, for example, the COVID-19 pandemic [11-14], but discussions of acceptance issues and conflict potentials have so far received little attention.

This paper aims at approaching this research gap and focuses on the question to what extent social conflict-understood here in Dahrendorf's sense $[15,16]$ as a supra-individual conflict with identifiable, opposing conflict parties and different conflict phases-is already advanced and to what extent-building on results on similar forms of protest, such as against renewable energies-socio-economic contexts are of importance. To this end, the theoretical framework will first be presented (Section 2) and the methodological approach explained (Section 3), with which the online presences of citizens' initiatives against the expansion of $5 \mathrm{G}$ were examined in a first quantitative-qualitative approach (Section 4) in order to identify future, we discuss the results by framing them with the theoretical framework (Section 5), more far-reaching conflict potentials and to provide outlooks in a conclusion (Section 6).

\section{Theoretical Framework}

The present study is a theory-driven empirical investigation. Theoretical foundations are Ralf Dahrendorf's conflict theory on the one hand and Pierre Bourdieu's theory of the distribution of symbolic capital on the other. Both can be described as 'medium-range theories' [17] that allow different perspectives on the protest against the expansion of the $5 \mathrm{G}$ network. With Dahrendorf, the phased nature of the conflicts as well as the possibilities and limits of their regulation can be understood; with Bourdieu, the embeddedness of the conflicts in social differences, which can be determined by the different availability of symbolic capital. Not only because of the triangulation of the two theoretical approaches, but also because of the empirical implementation, the intensive cooperation of different researchers and the use of data from different sources, our study can be classified in the tradition of 'neopragmatic spatial research' [18-20].

\subsection{The Social Conflict according to Ralf Dahrendorf}

According to Ralf Dahrendorf's conflict theory, a conflict should be called 'social' "if it can be derived from the structure of social units, that is, if it is supra-individual" [21] (p. 24). Social conflicts are, according to Dahrendorf $[22,23]$ to be found wherever there is social life, and thus represent, in addition to constant processes of change, the normal case of social conditions rather than the exceptional case (this section essentially follows Section 3 in [24]; see also in detail [25-30]). According to Dahrendorf, they are not to be regarded as fundamentally negative or even problematic, he rather points to the potential productivity of social conflicts for further social development and processes of change, which ideally lead to an increase in life chances for more people, especially through the formation and opening of ligatures ([31]; see on this in more detail [32,33]). Accordingly, social conflicts are embedded in social processes and occur in all societies, regardless of the form of government or political system. In this context, Dahrendorf notes the embeddedness of conflicts in four ubiquities:

- Ubiquity of change: every society is subject to constant and ever-present change;

- Ubiquity of conflict: every society knows social conflict;

- Ubiquity of productivity: each member of society contributes to the change of society;

- Ubiquity of domination: every society is characterized by power relations in which members of the society exercise power over other members (e.g., [21,34,35]).

Social conflicts follow, according to Dahrendorf [21] a regularity that can be divided into three phases of conflict unfolding:

(1) A first phase is characterized by the emergence of a structural initial situation in which subsets in society, called 'quasi-groups' by Dahrendorf, have the same latent interests, where 'latent interests' can be "all positional behavioral orientations (role expectations) [that] establish an oppositional relationship between two aggregates of 
positions, without the bearers of the positions necessarily being aware of them" [36] (p. 204).

(2) The second phase can be described as an awareness of latent interests, in which groups of shared interests are formed with an increasing external presence [21].

(3) In a third phase, the organized nature of the conflict takes place, in which the now organized conflict parties "with visible identities of their own" [21] (p. 36) emerge openly. Central to this is that the conflict takes on a dichotomized structure, i.e., polarizes into a pro or con that no longer allows for differentiations.

Social conflicts are subject to varying degrees of intensity and violence, whereby the intensity of a conflict expresses its social relevance (for example, in the case of high costs of defeat for the parties involved in the conflict), while the degree of violence can vary between the poles of more or less non-committal controversies up to loss-laden and destructive world wars (cf. [21]). On the one hand, it is necessary to keep the degree of violence low, on the other hand, however, it is also necessary to increase the maximization of life chances for the individuals in the sense of "rights of participation and an offer of activities and goods to choose from" [33] (p. 24).

In dealing with conflicts, according to Dahrendorf [15,21], basically three possibilities exist: (a) the suppression, (b) the solution as well as (c) the regulation of conflicts. Whereas in the case of suppression of conflicts, the conflict cannot be resolved and thus the intensity of the conflict and, as a consequence, the violence of the conflict increases, conflict resolution aims at the elimination of the social causes of the conflict, which Dahrendorf, regards as a utopian undertaking, since the underlying social causes of conflict are often rooted in the unequal distribution of power, which, however, is immanent in every society at all times and thus cannot be eliminated. A practicable way, on the other hand, is the settlement of conflicts, which is linked to four preconditions:

(1) A settlement requires the recognition of the existing conflict contradictions as a justified dimension of normality as opposed to their assessment as a state of affairs contrary to the norm.

(2) The conflict settlement to be sought does not refer to the causes, but to the manifestations of a conflict.

(3) In order to increase the efficiency of conflict settlement, a high degree of organization is required on the part of the conflict parties involved.

(4) The parties of the conflict are to be regarded as equals and previously established procedural rules that do not favor any of the parties involved are to be observed.

However, these preconditions require an institutional framework, which on the one hand implies the existence of a third authority that both sets binding guidelines for dealing with the conflict and also has the option of an external settlement of the conflict in the event that all negotiation options are exhausted [37]. On the other hand, the assignment of responsibility for decisions is a basic institutional condition (in liberal democracies, the regular assessment of elected representatives by the electorate; cf. [38]).

As societies modernize, they undergo far-reaching transformation processes that affect all levels of society. Nevertheless, gradual variances in the violence and intensity of conflicts can be identified in the recent past, whereas in modernity, 'major' social lines of conflict, such as clerical versus secular forces, labor versus capital, dominated Marx's class struggle, which were often accompanied by a high degree of violence and intensity, [39] in the postmodern era, against the background of growing prosperity in the former industrial nations and increased individualization, a series of micro-conflicts of limited violence and intensity developed $[15,22,40,41]$. At present, in the course of simplified and immediate access to public spheres through media instruments such as the world wide web and the corresponding content-generating and content-processing tools available at any time, such as smartphones, tablets, PCs, etc., there seems to be a tendency to combine individualized and differentiated cleavages of postmodernity with the efficacy of 'large' social conflicts and thus to develop a certain modern-postmodern hybrid form. These increasingly differentiated cleavages (for instance, on issues concerning 
gender, race, values, migration, conspiracy, religious orientation, property, social reforms and much more) develop an increase in intensity and sometimes brutality through digitally amplified public spheres as well as an increasing social tendency towards (re)ordering dichotomizations.

These tendencies can also be observed in the conflict over the introduction of 5G, when, for example, the social conflict according to Dahrendorf's phase model has sometimes reached phase two locally/regionally, and in parts already phase three: On the one hand, as will be shown in the following, an increased number of organized conflict parties with visibly separate identities are forming, for example in the form of local to national citizens' initiatives against 5G or mobile communications, which are also networking more closely with each other. On the other hand, however, dichotomizing structures of moral good vs. evil are also emerging beyond factual issues, which no longer tolerate any further differentiations. Moreover, the violence of the social conflict over 5G is increasing when, for example, in parts of Europe targeted arson and fuel attacks are carried out on physical manifestations such as $5 \mathrm{G}$ masts (see et al. [7,8,42]).

\subsection{Types of Capital according to Bourdieu and Standard Socio-Economic Model}

While Dahrendorf focuses his interest on the course of conflicts as well as the possibilities of their regulation, but integrates the social causes of conflicts only marginally into his theory, the social causes of conflicts upstream can be framed with the help of Pierre Bourdieu's theory of symbolic capital and its distribution.

According to Bourdieu [43] capital is accumulated labor, which appears in material or immaterial incorporated form. Following Bourdieu, these types of capital determine the basic mechanisms and rules in our world. They thus determine which actors, whether individuals or groups, can enter which exchange relationships, which possibilities are open to them and how they are perceived by other actors; in short, the (non-)existence of different types of capital determines the possibilities of the actors in this world [43] (230f). This makes it clear why varieties of capital form a fruitful basis for this inquiry: if we assume that the varieties of capital limit the possibilities of the actors, then it can be assumed that the (non)presence of capital must also have an impact on the possibility of political participation, such as the formation and membership of a citizens' initiative. Here, a brief look at the different types of capital again illustrates how this model can serve as a basis for the following models.

The simplest type of capital is economic capital, which can be defined fundamentally as the existence of economic resources, such as money. This type of capital also plays an important role in the following models. Furthermore, important for this study is cultural capital. Bourdieu divides this again into incorporated cultural capital, which comprises the personal, incorporated accumulation of capital [43] (232ff) as well as objectified cultural capital, e.g., paintings or instruments [43] (235f) and institutionalized cultural capital, such as academic titles [43] (236f). For the models that follow, incorporated cultural capital is particularly crucial, as it includes internalized knowledge about democratic forms of participation. The last type of capital Bourdieu discusses is social capital, which results from group membership. This capital arises from mutual knowledge and recognition within a network of relationships [43] (p. 238). Social capital will be revisited especially in the Civic Voluntarism Model. Nevertheless, it should already be mentioned here that although social capital plays an important role in this analytical framework, there is no indicator which can represent it at the level of analysis chosen here.

Bourdieu establishes a meaningful, but very broad access to our focus of the question. Therefore, it seems to make sense to look a little to the right and left of the path in other academic disciplines for meaningful approaches to the field. Empirical participation research represents meaningful access. This discipline focuses, among other things, on the study of participation in social processes. In addition, it attempts to develop basic theories that explain why people participate in political participation opportunities [44] (p. 55). In the context of empirical participation research, political participation can be understood as 
activities that are voluntarily exercised by citizens and pursue the goal of exerting political influence [44] (p. 61). Citizens' initiatives thus correspond to the conditions of political participation and thus fall within the scope of this research discipline. One of the most influential models in empirical participation research regarding individual participation patterns is the Standard Socio-Economic Model [44] (p. 75), [45] (p. 92). According to this model, fundamental factors for political participation are primarily the availability of three resources: income, education and political knowledge [46] (71f). It can be emphasized that there is often a correlation between the level of education and income [45] (p. 92). The types of capital indicated by Bourdieu can be recognized here once more: income reflects economic capital, education reflects cultural capital, while political knowledge can be considered more precisely as the incorporated cultural capital. This capital, in this model, represents the resources that a person possesses to participate politically [46] (p. 72). These resources are confronted by information or opportunity costs that must be overcome in order to participate. These costs range from complex knowledge, such as the function of certain political institutions, to simple information, such as the location of the polling station [46] (71f). However, focusing only on resources does not seem to be entirely sufficient to also explain why individuals with higher capital become active more often. This problem can be clarified with the extension of the standard socioeconomic model by Schlozman et al. to the Civic Voluntarism Model [44] (p. 77), [47] (78f). With this extension, the third type of capital, social capital, then finds its way in.

On the one hand, social conflicts are inherent in the different endowments of individuals, groups of individuals, or social aggregates with the various types of capital. On the other hand, symbolic capital can also be used to shape the identity of a quasigroup and to improve one's position in social conflicts against those who do not have a higher endowment of symbolic capital. At this point, the complementarity of Bourdieu's and Dahrendorf's theories becomes clear. In the following, we will use this theoretical framework to analyze the social $5 \mathrm{G}$ conflicts in Germany.

\section{Methodical Proceeding}

In a Google keyword search for the keywords 'citizens' initiative'*'5G' in April 2021, 182 citizens' initiatives against 5G in Germany were identified in an iterative process, 74 had their own online presence in the form of their own homepage or a social media profile. Using the place names or the locations given in the imprint, an overview map of the local locations of the citizens' initiatives was created (see Figures 2 and 8). Using a matrix, the online presences were systematically examined with regard to the objectives pursued, alternative technologies proposed, arguments put forward, risk perception and (hyper) links set, whereby a quantitative evaluation was first carried out to identify possible accumulations and conspicuous features. In a second step, an in-depth qualitative analysis was carried out to work out argumentation patterns. The aim of the analysis was to examine the extent to which the conflict - in this case on the part of the 5G opponents-already has a dichotomized structure at the present time, i.e., is polarized into a pro or con that no longer permits any differentiation and makes a settlement more difficult.

In addition to this analysis, the spatial distribution of the citizens' initiatives should also be considered. Through the identification and location of the citizens' initiatives carried out previously, a spatial concentration of the citizens' initiatives, particularly in the south of the republic, became clear. One possible explanation can be found in the Bourdieu models of capital types and the standard socio-economic model listed in Section 2.2. These fundamentally assume that the (relatively increased) presence of varieties of capital increases the chance of political participation. Accordingly, individuals in citizens' initiatives would have a higher amount of capital. Since we do not have data on the members of the citizens' initiatives (micro level), a first approximation could be made via the macro level, since data on the different types of capital are available at the district level (with varying names in Germany referred to as Landkreis, Kreis, kreisfreie Stadt or Stadtkreis). Therefore, in the subsequent analysis, the number of citizens' initiatives in a 
district was intersected with various indicators of the presence of capital types, such as average household income or the proportion of employees with academic degrees. The correlations are detailed in Section 4.2. This procedure is, of course, only an approximation and can provide initial indications of whether the conclusions drawn from Bourdieu's model and from the standard socio-economic model represent a promising approach to the field in this context.

\section{Resistance to 5G-An Explorative Approach}

In the mass market for smartphone users, similar to the introduction of the predecessor technologies, further progress in terms of transmission rates and speed can be achieved by the new 5G standard, which was introduced in 2019. Although the new technology here 'merely' functions as a further development stage, 5G is considered to be of revolutionary importance. This becomes particularly clear in the area of commercial users, due to its radio technology properties, especially in the area of machine-to-machine communication but also critical mobile communication-i.e., when minor disruptions of communication cause considerable economic damage or even endanger human lives [48-52]. So far, however, a number of uncertainties accompany the rollout, such as how network operators will guarantee a 5G deployment, possible effects on the network architecture or debates about network security [53]. Even if the new technology is associated with great hopes for a boost in innovation in the most diverse sectors of an economy, there are increasing indications that the concrete technical implementation on the ground-as already in the context of the measures to implement the energy turnaround-may encounter considerable resistance from the local population. One reason might be, that the new 5G standard requires a significantly increased density of mobile phone masts [54-57], in particular, in high-density areas such as cities [58-60].

In Germany, 5G network rollout is currently (as of July 2021) being implemented by the providers Deutsche Telekom, Vodafone and Telefónica, with the companies communicating not the specific 5G sites installed, but rather the network coverage achieved. According to the companies, Deutsche Telekom reached 66 million people at the end of March, or about $80 \%$ of the German population, with $90 \%$ of users expected to have access to $5 \mathrm{G}$ network coverage by the end of 2021-meaning Deutsche Telekom currently operates the largest 5G network in Germany, with about 50,000 antennas in 5000 cities [61]. Vodafone, with more than 7000 antennas, was providing $5 \mathrm{G}$ reception to around 20 million people as of February 2021, and aims to offer coverage to over 30 million people in Germany by the end of 2021, while Telefónica (as of March 2021) provides 5G coverage to thirty major German cities [61]. Accordingly, large parts of the population already have access to the $5 \mathrm{G}$ network, but isolated 5G coverage gaps remain, particularly concentrated in eastern Germany (see Figure 1). 


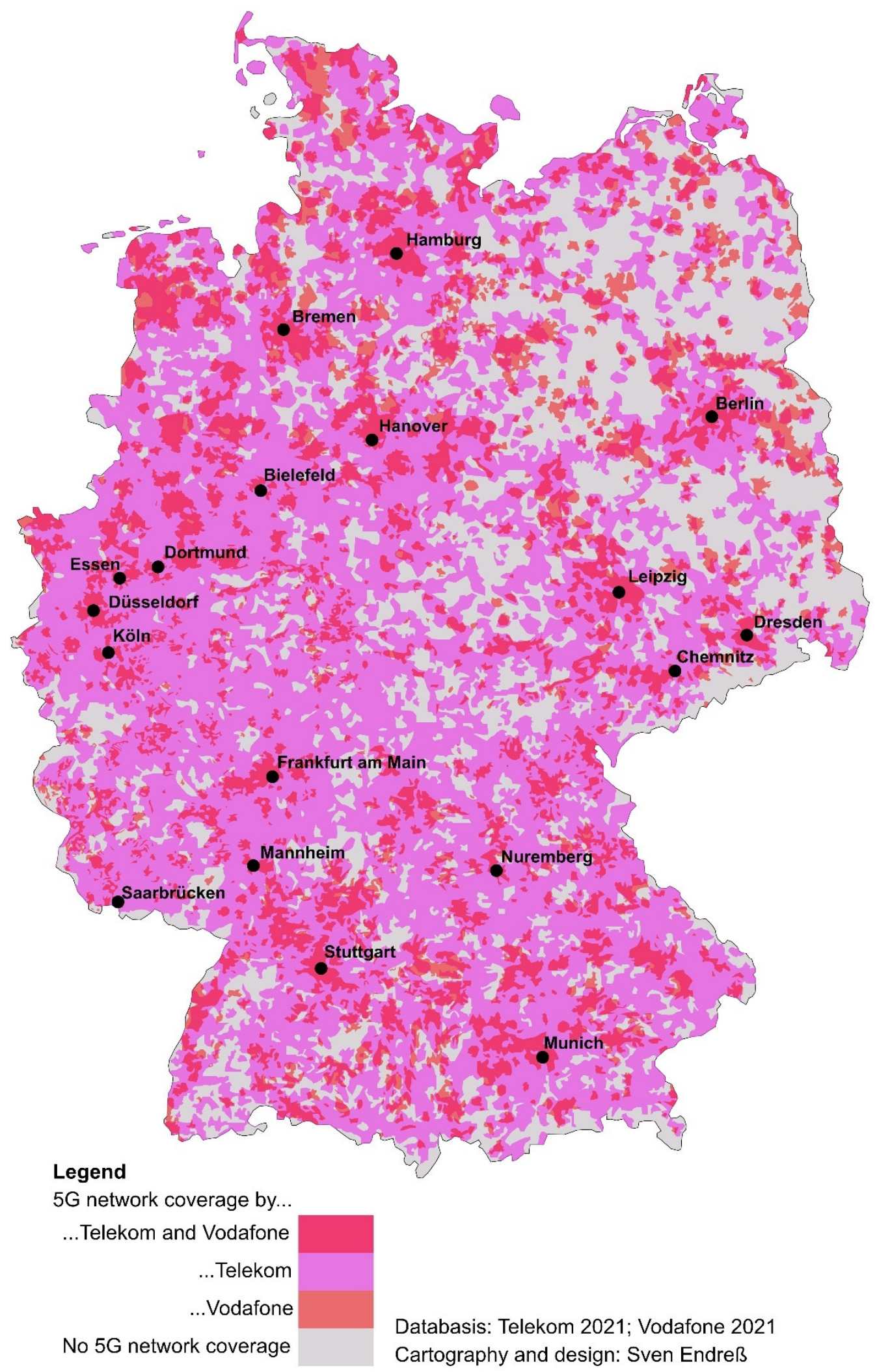

Figure 1. Network coverage of the two largest 5G providers in Germany: Deutsche Telekom and Vodafone; own illustration on the basis of Telekom [62] and Vodafone [63].

In the course of further extensive social transformations and technical innovations in Germany, for example, the implementation of the energy transition resistance to the implementation plans was formed, in the context of which quasi-groups with the same 
latent interests and an increasing external presence were formed, and in the course of which dichotomizing camps of pro and con were formed (see among many: [24,64-67]), whereby the controversies here often moved from factual argumentation to a morally conducted dispute [68-70] and thus made conflict resolution more difficult. As already shown with the emergence of citizens' protests against the local implementation of physical manifestations of the energy transition (wind turbines and power lines), the emergence of counter-movements such as citizens' initiatives is not necessarily related to the appearance of the projected or later implemented facilities [64]. On the one hand, it is possible to identify spatial concentrations of citizens' protests, which, in the case of wind energy plants, are concentrated in the (south) west of Germany and, in the case of power line projects, on certain routes in North Rhine-Westphalia and, in particular, in Bavaria (cf. [64]), on the other hand, a clustering of citizens' initiatives can be observed in areas that-as in the case of 5G-are not extraordinarily more affected by 5G than other regions (see Figure 1), but nevertheless show an increased number of citizens' initiatives against 5G, such as in parts of Bavaria and Baden-Württemberg (see Figure 2).

\subsection{Objectives and Lines of Argumentation of the Opponents}

In an analysis of the online presences of citizens' initiatives against 5G $(n=182$; with evaluable online presences $n=74$; based on the google keyword search 'citizens' initiative ${ }^{\prime \prime \prime} 5 \mathrm{G}^{\prime}$ in April 2021), a thoroughly more heterogeneous goal orientation of the various initiatives emerges than it could be observed, for example, in the context of the protests against manifestations of the energy transition, in which the primary goal was the prevention of a concrete project $[24,64,71]$. Only about half of the identified citizens initiatives explicitly oppose 5G, the others are directed against electromagnetic fields, mobile radio or radiation exposure in general (cf. Figure 3) and can thus be placed in a tradition of public protest against the technology for the use of mobile radio devices, which has already existed since the introduction of mobile radio. Overall, there is a general rejection of radio technology, with only a tiny proportion calling for more research (see Figure 3). Conversely—as will be shown - arguments against $5 \mathrm{G}$ refer to the incomplete state of knowledge.

Alternatives to mobile communications are seen in particular in wired solutions such as fiber optics or broadband, but also wireless transmission technologies such as Visible Light Communications (VLC) (cf. Figure 4), in the latter case data are transmitted with visible light, but the ranges are limited to rooms (see in detail at [72-74]). 


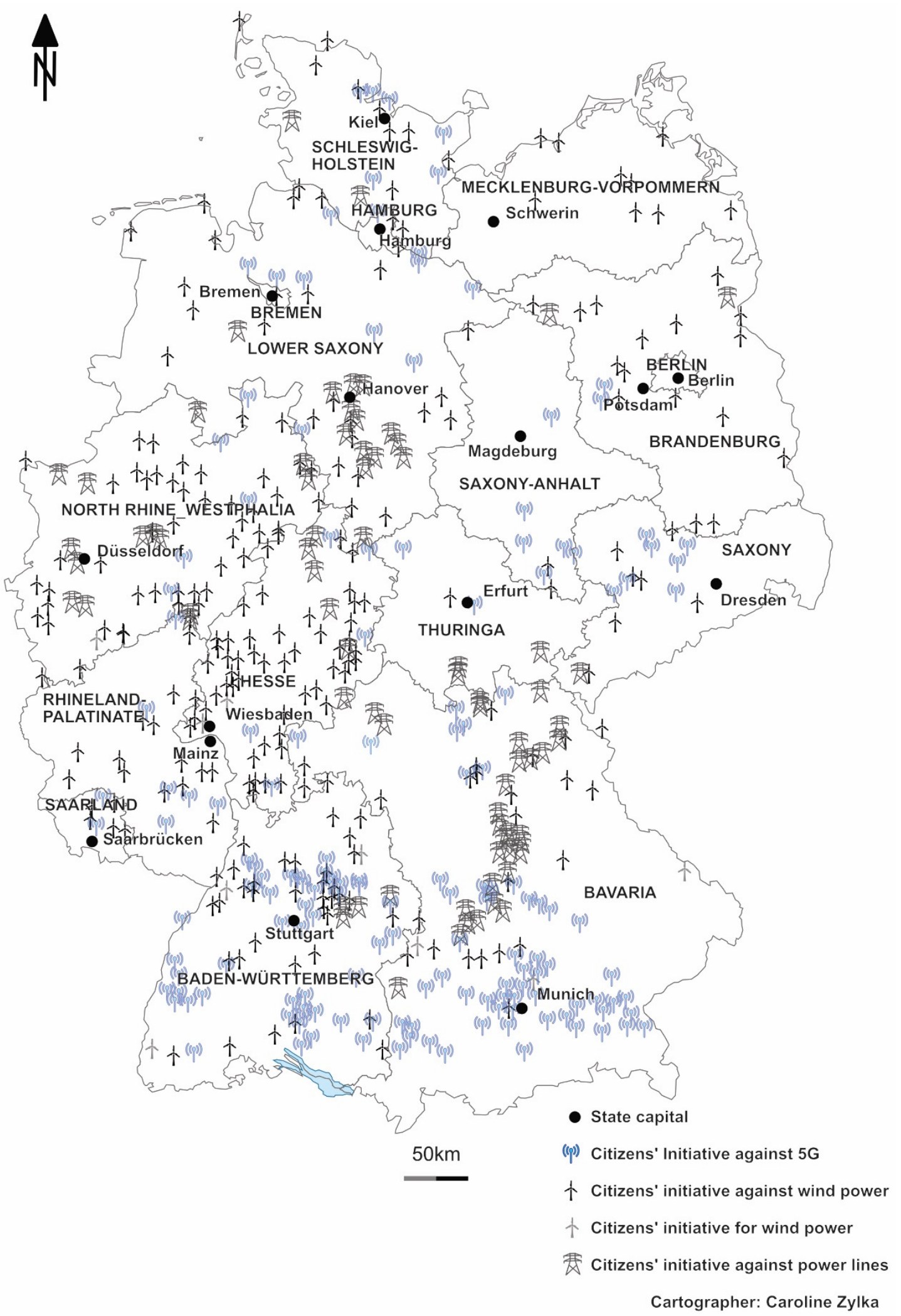

Figure 2. The distribution of citizens' initiatives with online presences against national technology transformations such as Energy transition (here against wind energy and upgrading of electricity grids) and 5G (own survey and representation). 


\section{Goals of citizens' initiatives \\ (stated on their websites; $\mathrm{n}=74$ )}

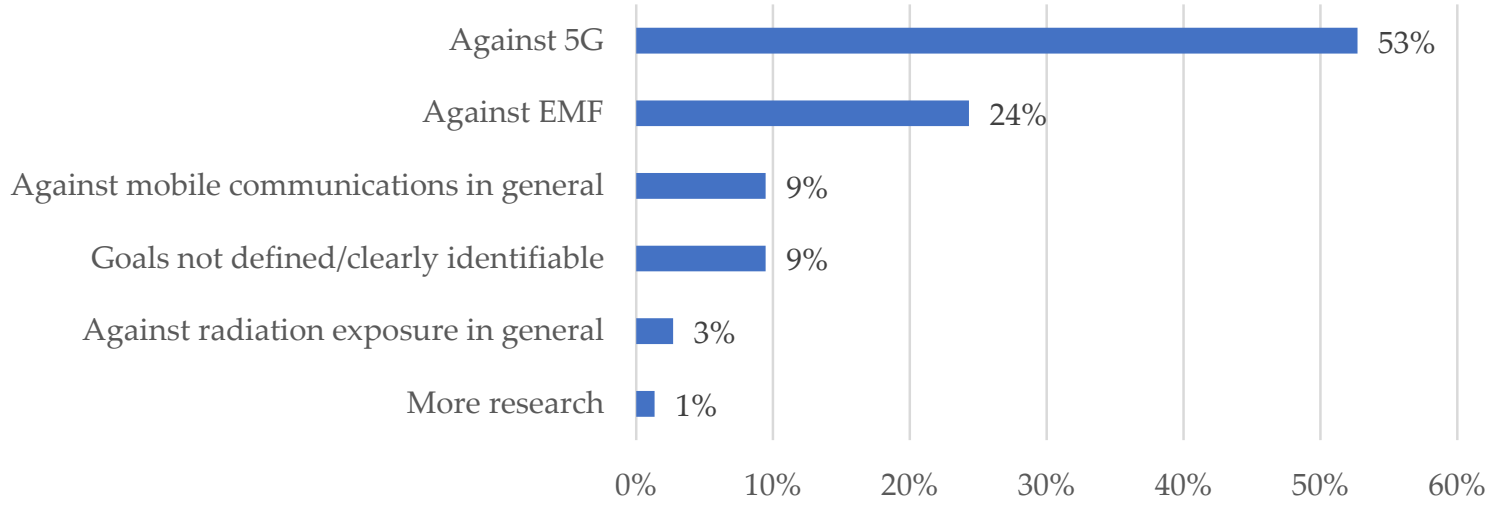

Figure 3. Goals of the citizens' initiatives against 5G (own survey and presentation).

\section{Alternatives according to 5G citizens' initiatives (stated on their websites; $\mathrm{n}=74$ )}

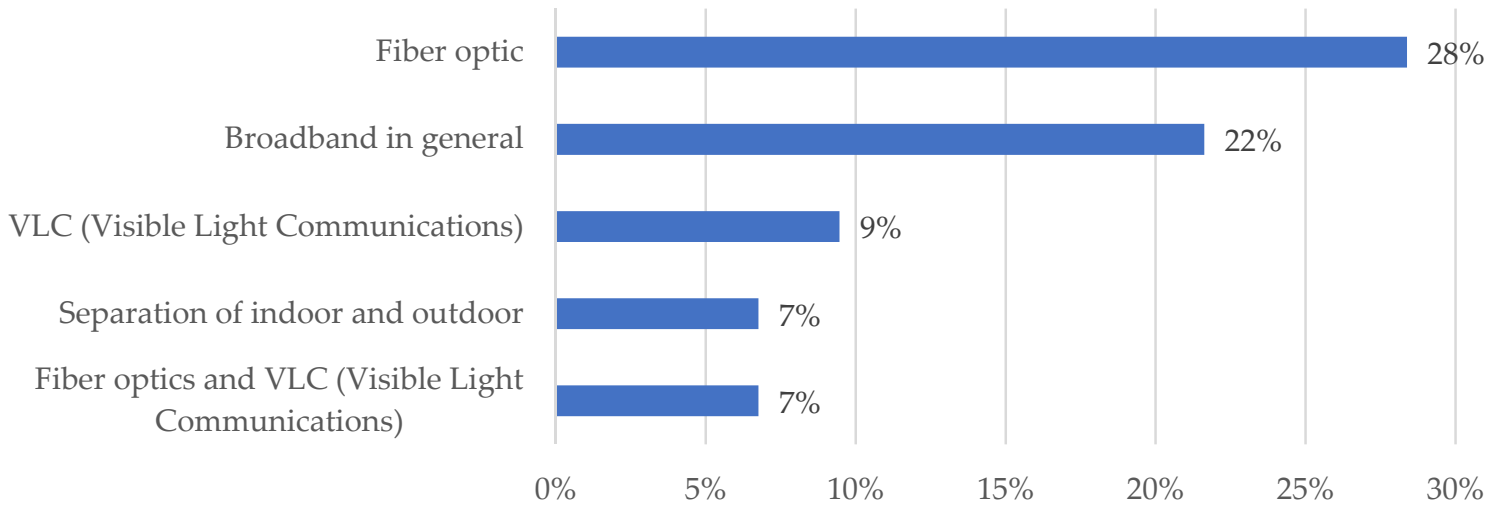

Figure 4. Discussed alternatives to mobile technology on websites of 5G citizens' initiatives (own survey and presentation).

The arguments presented are primarily aimed at health concerns, followed by arguments related to nature conservation or the environment in general, which fear effects on plants and animals as well as the disturbance of natural electromagnetic fields and thus target the radiation aspect of mobile communications technology or 5G (Figure 5). Due to its omnipresence, the radiation cannot be avoided [75] and causes oxidative stress in humans, animals and plants and increases the risk of cancer in living beings (see also Figure 6). To reduce inevitable radiation exposure, opponents recommend removing "amalgam or metallic dental bridges [... ] screws, wires or similar after bone fractures or tendon ruptures in the body" because "[a]ll metal that is in your body increases the receptivity of this 'antenna'!" [76] (w.p.). For strengthening and self-stabilization, a comprehensive life adjustment is suggested with autogenic training, the avoidance of industrially produced food, the wearing of ESD shoes (esd = electrostatic discharge) and deacidification (e.g., [76,77]). In addition, concerns are raised about the possibility of more comprehensive monitoring or a softening of data protection, which would turn users into 'transparent people' (see, e.g., 'The Data Protection Act') [78]. Furthermore, it is argued that the state of knowledge about $5 \mathrm{G}$ is still incomplete, so that the state must act according to the precautionary principle, drawing parallels to historical misjudgments about asbestos, smoking or chemicals policy (among many others: [78,79]). In many cases, however, this does not result in a far-reaching demand for further research, but rather in a categorical rejection (see Figures 3 and 5). A 
further argument consists of a feared increase in resource consumption and the creation of an infrastructure that increases the danger of global (cyber) wars [79].

\section{Arguments against 5G according to citizens' initiatives (stated on their website; $\mathrm{n}=74$ )}

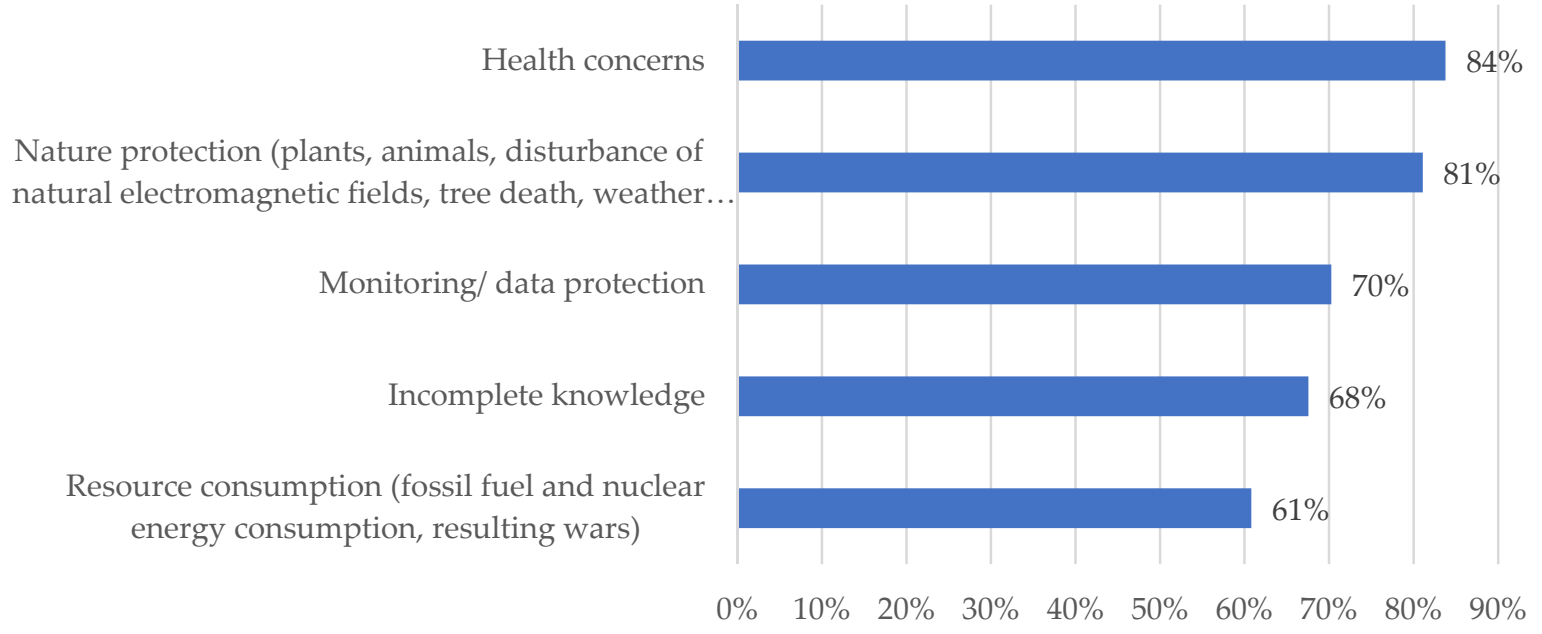

Figure 5. Arguments against 5G presented on the online sites of citizens' initiatives (own survey and presentation).

In terms of risk assessment, the fear of an increased cancer risk due to mobile communications in general and $5 \mathrm{G}$ in particular ranks first, followed by an assumed general risk due to the increase in electro-smog associated with 5G (Figure 6). There is also the assumption, that the increase in high-frequency electromagnetic fields leads to brain damage and tumors and causes oxidative stress, whereby children in particular are exposed to a special health risk due to the process of digitalization of schools and the associated expansion of W-LAN hotspots [79]. Furthermore, the communication and information on 5G are believed to be untrustworthy and not very comprehensive-rather, economic interests are in the foreground in the expansion of 5G (e.g., [80]).

\section{Risk assesment of citizens' initiatives (stated on their website; $\mathrm{n}=74$ )}

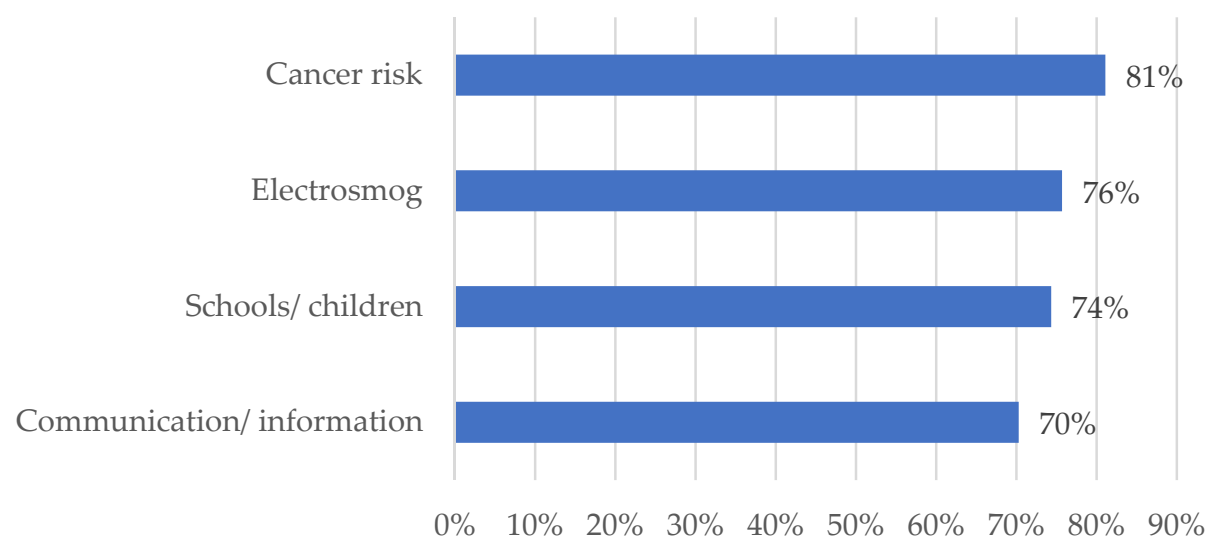

Figure 6. Risk assessment of 5G as well as mobile radio in general on the online sites of the citizens' initiatives (own survey and presentation).

The arguments put forward and perceived risks are supported in the online presences of the citizens' initiatives in particular by numerous links to primarily other protest websites 
against $5 \mathrm{G}$ - even if around $20 \%$ of the online presences do not have any further links over a third of the identified online presences of citizens' initiatives present 26 further links and more to support the arguments, concerns and perceived risks expressed. If we look at the respective links in detail, we see that over $40 \%$ of the links identified, and thus by far the largest proportion of the links set, refer to other online portals of $5 \mathrm{G}$ opponents, such as other citizens' initiatives, associations, foundations, etc. (Figure 7) and thus a discursive closure in the 5G opposition can be stated. In particular, the websites of diagnose-funk.org and kompetenzinitiative.com (both accessed on: 5 December 2021) stand out, which represent one of the central sources for numerous citizens' initiatives against $5 \mathrm{G}$ and whose actors frequently appear as lecturers and guest speakers or authors-often with the indication that the 'true' or 'correct' experts from the fields of medicine, engineering, etc. should have their say, who would not be heard or would not be heard sufficiently in the public discourse and by government decision-making bodies (e.g., $[75,79])$. The second largest share among the links is represented by videos and YouTube documentaries with $16 \%$. These, for example, explain the correlations of health consequences of radiation. The videos and YouTube documentaries are followed by newspaper articles and online portals on potential risks, whereas study results and scientific journal articles with $8 \%$ and $5 \%$, respectively, receive only marginal consideration, as do political papers (Figure 7).

\section{Links on citizens' initiatives websites \\ (citizens' initiatives-n=74; linking-n=865)}

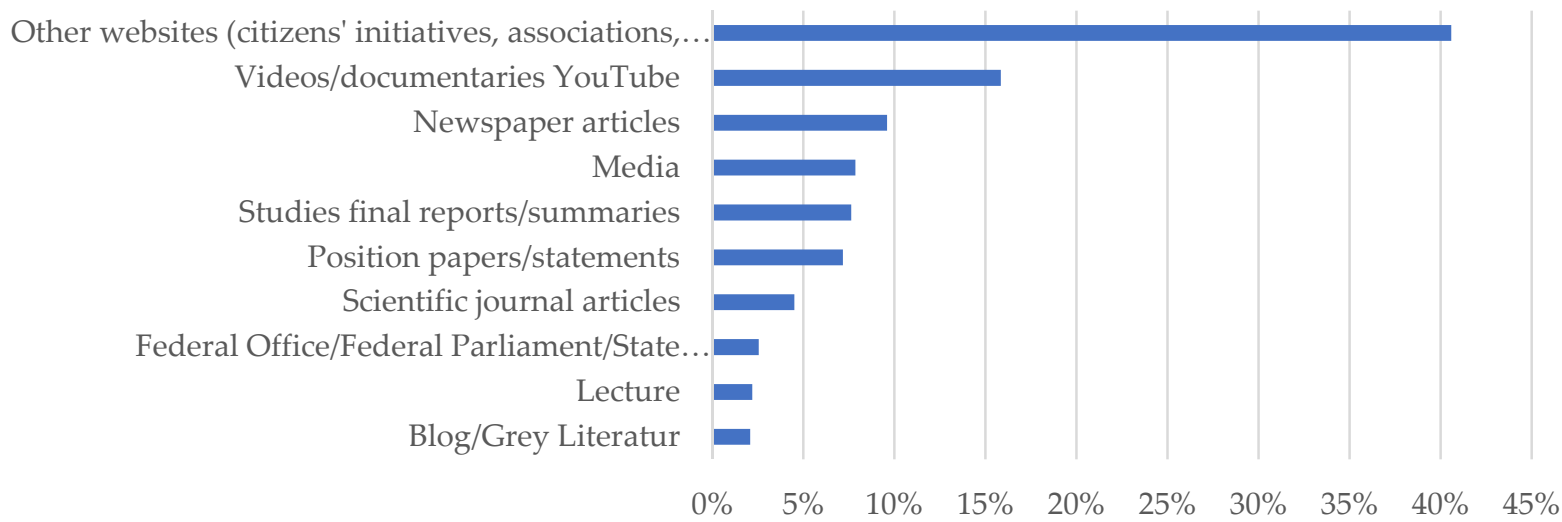

Figure 7. Links on the websites of citizens' initiatives (own survey and presentation).

Accordingly, a settlement seems unlikely against the background of the previous results, since the argumentation is often transferred to an emotional-moral level and there is no common shared basis in what can be considered 'true'. Accordingly, the other side is not recognized as equal, which, according to Dahrendorf, however, is a basic prerequisite for the settlement of conflicts. The possibility of potentially spreading unverified information worldwide and reinforcing it in echo chambers instead of striving for a commonly shared basis can be cited here as a central problem.

\subsection{Socio-Economic Contexts}

Previous findings on new forms of protest movements, which asked in particular about protagonists and active (founding) members, show that it is primarily individuals with an often above-average formal highest educational attainment-usually financially secure, looking back on a successful career-combined with the corresponding abilities to accumulate, communicate and distribute information and positions or-with Bourdieu [81] — to put it another way, a high endowment of symbolic capital, are engaged in protest movements against specific large-scale infrastructure projects $[65,71,82]$ whereas protest movements against general, overarching goals such as climate change are more 
likely to be characterized by people of younger age with a higher level of formal education but a (still) low level of financial capital [83,84]. Based on a protest movement directed against concrete infrastructure measures such as the expansion of the $5 \mathrm{G}$ network in Germany, the correlation of the identified citizens' initiatives against 5G and the average household income at the district level of the federal states clearly shows that citizens' initiatives against 5G are particularly prevalent in those districts with a relatively high average household income (cf. Figure 8) and would thus support previous findings in this regard.

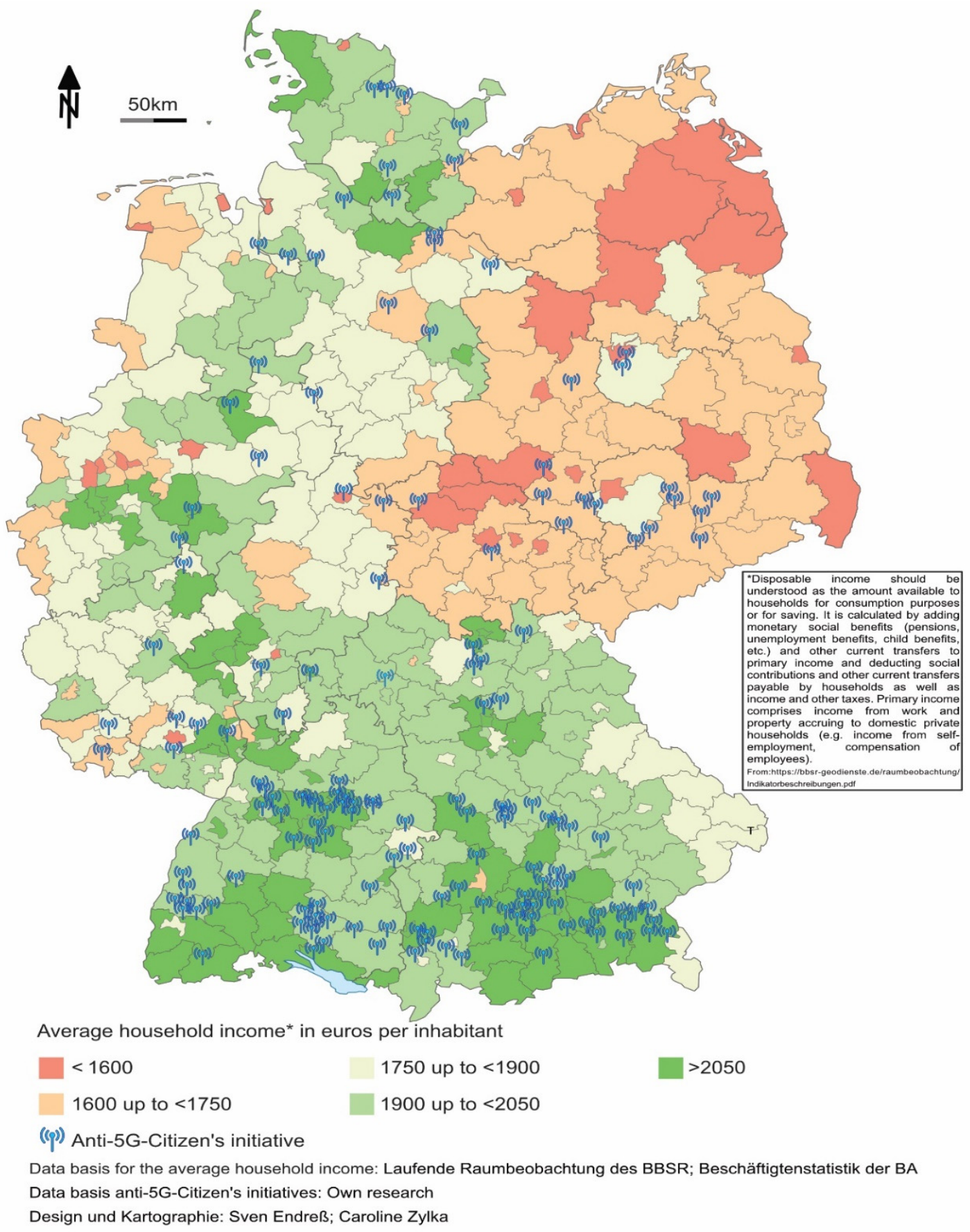

Figure 8. Synthesis of the distribution of citizens' initiatives against $5 \mathrm{G}$ and the average household income in euros per inhabitant (own representation). 
Following this finding, other socioeconomic indicators at the district level were also compared with the number of citizens' initiatives against 5G there. This approach can provide initial insights into possible relationships between socio-economic indicators and citizens' initiatives, which can then be investigated more closely in further studies, particularly in qualitative interviews with members of citizens' initiatives.

Via the so-called resistance and networking map of the anti-5G citizens' initiative diagnose:funk [85], it was possible to locate the citizens' initiatives active in Germany. Thereby, 164 initiatives were identified and located on a district level $(n=402)$. As socioeconomic resources, the indicators unemployment rate (2014), average gross earnings (2014), median income (2014), tax power of the district (2014) disposable income (2018) and building land prices (2014) were used for economic capital. For cultural capital, the indicators share of employees in knowledge-intensive industries (2014) and share of employees with academic degrees (2014) were used.

Let us first look at the economic capital of districts compared to their number of citizen initiatives: contrasting the 2014 unemployment rate [86] and the citizens' initiatives, a small negative correlation $(-0.188)$ can be seen, the result is highly significant $(p=0.000)$. Thus, a higher economic capital seems to be related to a higher number of citizens' initiatives. Similar results are obtained when looking at other economic indicators: the average gross income in 2014 [86] correlates slightly positively (0.193) with the number of citizens' initiatives $(p=0.000)$. Very similar results are also obtained, for the analysis of the median income in $2014(0.194)$ as well as the tax power in 2014 (0.197) [86]. Both results are also highly significant here $(p=0.000)$.

Next, the disposable income of households was examined, and it should be noted that this data set also includes the disposable income of non-profit private organizations [87]. It should also be noted that due to a different district breakdown, only 400 counties were examined here, with no data available for Bremen and Bremerhaven $(n=398)$. Here, a medium correlation (0.236) is shown, the result can be classified as highly significant $(p=0.000)$.

The last indicator of economic capital to be considered is the price of building land. The price of building land should give a fairly good indication of the economic resources available locally. A positive correlation with the number of citizens' initiatives would therefore be expected here. If we look at the results, this assumption is confirmed: a medium correlation (0.342) can be identified, which is highly significant. It should be noted that data on building land prices were only available for 388 counties.

In addition to the economic capital of the districts, the cultural capital should also be compared with the number of citizens' initiatives.

The first indicator to be considered is the share of employees in knowledge-intensive industries. Here, it can be assumed that an increased share indicates a higher cultural capital, since people working in knowledge-intensive industries usually have a higher education. It shows a low correlation (0.147), whereby the result can be classified as highly significant $(p=0.003)$.

Finally, the proportion of employees with an academic degree will be examined in more detail, as an academic degree is a good indicator of cultural capital. There is a medium correlation (0.243), whereby the result is highly significant $(p=0.000)$.

\section{Discussion}

The findings discovered here suggest that increased economic capital, as well as increased cultural capital, are positively related to the formation of citizens' initiatives against 5G. A higher endowment of symbolic capital thus facilitates the formulation of interest and the formation of a conflict party. Here, we are referring to inferences from the macro level to the micro level, which is why it should be clearly emphasized again that these findings can only serve as indications for further research in this area and should by no means be understood as sufficient justifications for the phenomena presented here. 
In addition to these indications for further questions, these findings may also provide new theoretical approaches to research on anti-5G citizens' initiatives: the results obtained suggest that socio-economic indicators may be related to the number of citizens' initiatives formed. Accordingly, approaches that focus on socio-economic resources would possibly be promising. Thus it is conceivable that Bourdieus access [43] on the different types of capital and their (non-)availability could provide fertile ground for further research. In addition to the very general approach via Bourdieu, scientific access via empirical participation research also seems worthwhile. As stated before, one of the most influential models in empirical participation research with regard to individual participation patterns is the Standard Socio-Economic Model [44] (p. 75), [45] (p. 92). In this model, fundamental factors for political participation are primarily the availability of three resources: income, education and political knowledge [46] (71f). This also shows the close links to Bourdieu's approach. If future analyses should also focus more on social capital, reference should be made to the extended approach of the Standard Socio-Economic Model, the so-called Civic Voluntarism Model, which also focuses on the influence of networks, among other things [47] (p. 50). Particularly for future qualitative analyses, the extended points in this model, such as strong personal involvement in a problem area, could be used (in relation to 5G, for example, a perceived electro sensitivity would be conceivable here) [47] (p. 64).

With regard to the character of the conflict studied, it can be said that the protest against the expansion of the 5G network has numerous parallels to protests against measures against the spread of COVID-19, but also against the expansion of plants for the renewable generation of electricity, the power grid in the context of the energy transition, but also other spatially affecting changes, such as the extraction of mineral raw materials or industrial estates [88-94]. The bearers of the protest are mostly people with a higher stock of symbolic capital, i.e., also the ability to use scientific results specifically for their own purpose. This use of incorporated cultural capital goes so far that conspiracy theories are developed. A widespread view refers to elites (i.e., including the scientist) representing personal interests alone for example [94,95]. On the 'opposing' side the demand is made that every single statement has to be finally verified, which from the perspective of scientific theory reveals a strong asymmetry between the claim to one's own and the opposing position. This asymmetry is not addressed in the corresponding conflicts and ultimately forms an aspect of the escalation of social conflicts.

Another point that should be addressed is the spatial distribution of 5G. After all, it could be assumed that in the areas with no or only a few citizens' initiatives, there have simply been no measures to install $5 \mathrm{G}$ yet. If there is no roll-out of $5 \mathrm{G}$ in a region, then there would be little point in a citizens' initiative against the roll-out. However, when looking at the network maps for the 5G roll-out of Telekom and Vodafone (see Figure 1), it becomes apparent that there do not seem to be any spatial patterns that support this fear. This finding indicates that the commitment on the part of the citizens' initiatives is not solely about keeping one's own residential environment free of transmission masts (Not In My Backyard-NIMBY). Although the argumentation patterns encountered also refer in part to this much-discussed phenomenon [96-98], in that individual sites are subject to criticism, the argumentation patterns are often characterized by a fundamental rejection of mobile communications in general and 5G in particular. Health concerns about the technology are particularly prominent in this context. Frequently, there is also a general skepticism of technology and modernization, which is not least connected to the ideas of the German Romanesque period about a traditional unity of nature and culture [88,99-101]. Criticism of planning procedures, which are not considered to be sufficiently sensitive to local peculiarities, is directed in a similar direction. Although similar patterns of argumentation can be found in the context of other spatial conflicts, such as in relation to wind turbines, power grids, or even facilities for the extraction of raw materials [82,102-104], these-as a result of their greater visual presence-exhibit a stronger NIMBY significance. In this respect-if a concise acronym is to be used-the acronym NOPE (Not On Planet Earth) can rather be used for characterization in the case of resistance to $5 G[90,105]$. At the same 
time, it could make sense for further studies to focus more on this phenomenon in order to generate reliable data in relation to 5G.

\section{Conclusions}

Accordingly, the analysis of the online presence of 5G opponents shows that the initiatives involved have a high degree of organizational capacity and interconnectedness, which is generated and reinforced in particular by the closed exchange from within themselves. This often hermetic closedness of the discourses in the organized conflict parties with an increasing external presence leads to a dichotomized structure, i.e., polarizes into a pro or con, which no longer allows for differentiations and thus makes regulation difficult. As shown, for a successful conflict regulation-in the sense of Ralf Dahrendorf-the existence of an agreement on essential elements of world interpretation is necessary, i.e., a consensus both on what is accepted as 'true' and on which procedures of conflict regulation should be applied. For both, there is no consensus on the part of the conflict parties. As a result, the conflicts surrounding the expansion of $5 \mathrm{G}$ are unable to realize their constructive potential. The situation is further complicated by the fact that the state is unable to adopt a neutral position with regard to the conflicts surrounding the expansion of $5 \mathrm{G}$, as it is pushing the expansion and thus becoming a party to the conflict itself. This results in a rapid transformation from a factual conflict to an identity conflict (us versus the economy/state) and even to a fundamental system opposition. The spatial concentration of the occurrence of initiatives in regions with an above-average household income also supports the thesis already established in similar forms of protest-such as in the context of the energy transition-according to which in particular people with a high symbolic capital in Bourdieu's sense of the term [81] develop activation potentials in the context of citizens' initiatives and are able to mobilize other people.

The study conducted with regard to spatial distribution supports the thesis that both cultural and economic capital have an influence on participation behavior with regard to anti-5G citizens' initiatives. The spatial clustering of citizens' initiatives in BadenWürttemberg and Bavaria, especially in the vicinity of the state capitals, can therefore be explained, at least in part, by the increased presence of these types of capital. Since, as already mentioned in the discussion, the available resources can only partly contribute to the explanation of participation behavior, further research should be conducted on this topic, especially with regard to personal involvement, motivation and social capital. This is probably best done through qualitative interviews. A quantitative method as undertaken here seems insufficient for these topics. Furthermore, it would be interesting to conduct research that examines the indicators used here for other citizens' initiatives, such as in the field of wind power, in order to find out whether the correlations observed here can also be found in other topic areas.

With regard to the neopragmatic research strategy of combining Ralf Dahrendorf's conflict theory and Pierre Bourdieu's class theory, a high degree of complementarity can be observed: while Dahrendorf focuses on the course of social conflicts and their regulatability, the use of Bourdieu's capital theory offers insights into the formation of the conflict parties with regard to the availability of symbolic capital, but also with regard to its use for their own purposes in the course of the conflict (one element is the ability of the cultural capital and social capital incorporated for use to generate and disseminate internet presences).

Author Contributions: Conceptualization, C.J., S.E. and O.K.; methodology, C.J., S.E. and O.K.; software, C.J., S.E., O.K. and C.Z.; validation, C.J., S.E., O.K. and C.Z.; formal analysis, C.J., S.E. and O.K.; data curation, C.J., S.E. and O.K.; writing-original draft preparation, C.J., S.E. and O.K.; writing-review and editing, C.J., S.E. and O.K.; visualization, C.J., S.E. and C.Z.; supervision, C.J. and O.K.; project administration, C.J. and O.K. All authors have read and agreed to the published version of the manuscript.

Funding: This research was funded by Federal Office for Radiation Protection (Bundesamt für Strahlenschutz), grant number FKZ: 3620 S82476. 
Institutional Review Board Statement: Not applicable.

Informed Consent Statement: Not applicable.

Data Availability Statement: The data is stored on the servers of the University of Tübingen.

Conflicts of Interest: The authors declare no conflict of interest.

\section{References}

1. Bundesregierung. Digitalisierung Gestalten: Umsetzungsstrategie der Bundesregierung. Available online: https://www. bundesregierung.de/resource/blob/992814/1605036/ad8d8a0079e287f694f04cbccd93f591/digitalisierung-gestalten-downloadbpa-data.pdf?download=1 (accessed on 27 April 2021).

2. NTIA National Telecommunications and Information Administration. National Strategy to Secure 5G Implementation Plan. Available online: https://www.ntia.gov/files/ntia/publications/2021-1-12_115445_national_strategy_to_secure_5g_implementation_ plan_and_annexes_a_f_final.pdf (accessed on 27 April 2021).

3. Ministère de L'Économie, des Finances et de la Relance. Stratégie D’accéleration sur la 5G et les Réseaux du Futur. Available online: https://www.entreprises.gouv.fr/fr/actualites/numerique/ressources/strategie-d-acceleration-sur-la-5g-et-reseauxdu-futur (accessed on 27 April 2021).

4. Department for Digital, Culture, Media \& Sport. 5G Supply Chain Diversification Strategy. Available online: https:/ /www.gov. uk/government/publications/5g-supply-chain-diversification-strategy/5g-supply-chain-diversification-strategy (accessed on 27 April 2021).

5. Department of Telecommunications India. 5G India 2020: 5G-A Next Generation Wireless Technology. Available online: https:/ / dot.gov.in/5g-india-2020 (accessed on 29 April 2021).

6. Bvmde. Bündnis Verantwortungsvoller Mobilfunk Deutschland. Available online: https://bvmde.org/ (accessed on 10 September 2021).

7. Scheuer, S. Verschwörungstheorien Motivieren zu Anschlägen auf 5G-Masten: In Europa Kommt es Vermehrt zu Anschlägen auf 5G-Masten. Grund Dafür sind Verschwörungstheorien, die Mobilfunkstrahlung für die Corona-Pandemie Verantwortlich Machen. Available online: https:/ / www.handelsblatt.com/politik/deutschland/coronavirus-verschwoerungstheorien-motivieren-zuanschlaegen-auf-5g-masten/25770420.html?ticket=ST-11403903-oe55e1dR0tKdSPkVqVGU-ap5 (accessed on 19 July 2021).

8. Satariano, A.; Alba, D. Burning Cell Towers: Out of Baseless Fear They Spread the Virus. Available online: https://www.nytimes. com/2020/04/10/technology/coronavirus-5g-uk.html (accessed on 19 July 2021).

9. Nakashima, E. DHS to Advise Telecom Firms on Preventing 5G Cell Tower Attacks Linked to Coronavirus Conspiracy Theories. Available online: https:/ / www.washingtonpost.com/national-security/dhs-to-advise-telecom-firms-on-preventing-5g-celltower-attacks-linked-to-coronavirus-conspiracy-theories/2020/05/13/6aa9eaa6-951f-11ea-82b4-c8db161ff6e5_story.html (accessed on 10 September 2021).

10. Wittekindt, W. Brandanschlagsserie auf Handymasten in Saarlouis. Available online: https://www.sr.de/sr/home/nachrichten/ panorama/brandanschlaege_auf_handymasten_saarlouis_100.html (accessed on 10 September 2021).

11. Sturm, T.; Albrecht, T. Constituent Covid-19 apocalypses: Contagious conspiracism, 5G, and viral vaccinations. Anthropol. Med. 2020, 1, 122-139. [CrossRef]

12. Bruns, A.; Harrington, S.; Hurcombe, E. 'Corona? 5G? or both?': The dynamics of COVID-19/5G conspiracy theories on Facebook. Media Int. Aust. 2020, 177, 12-29. [CrossRef]

13. Jolley, D.; Paterson, J.L. Pylons ablaze: Examining the role of 5G COVID-19 conspiracy beliefs and support for violence. Br. J. Soc. Psychol. 2020, 59, 628-640. [CrossRef]

14. Meese, J.; Frith, J.; Wilken, R. COVID-19, 5G conspiracies and infrastructural futures. Media Int. Aust. 2020, 177, 30-46. [CrossRef]

15. Dahrendorf, R. Der Moderne Soziale Konflikt: Essay zur Politik der Freiheit; Deutsche Verlags-Anstalt DVA: Stuttgart, Germany, 1992; ISBN 3-421-06539-X.

16. Dahrendorf, R. Sozialer Konflikt. In Wörterbuch der Soziologie; Bernsdorf, W., Ed.; Ferdinand Enke Verlag: Stuttgart, Germany, 1969; pp. 1006-1009.

17. Merton, R.K. The Sociology of Science: Theoretical and Empirical Investigations; University of Chicago Press: Chicago, IL, USA, 1973; ISBN 0226520927.

18. Zepp, H. Das Neue Emschertal. Transformation von Freiräumen und Veränderung von Ökosystemleistungen während der letzten 200 Jahre. In Landschaft als Prozess; Duttmann, R., Kühne, O., Weber, F., Eds.; Springer VS: Wiesbaden, Germany, 2020; pp. 327-360.

19. Kühne, O.; Jenal, C. Baton Rouge-A Neopragmatic Regional Geographic Approach. Urban Sci. 2021, 5, 17. [CrossRef]

20. Kühne, O. Reboot "Regionale Geographie"-Ansätze einer neopragmatischen Rekonfiguration "horizontaler Geographien". Berichte. Geogr. Landeskd. 2018, 92, 101-121.

21. Dahrendorf, R. Konflikt und Freiheit: Auf dem Weg zur Dienstklassengesellschaft; Piper: München, Germany, 1972.

22. Dahrendorf, R. Zu einer Theorie des sozialen Konflikts [1958 erstveröffentlicht]. In Theorien des Sozialen Wandels; Zapf, W., Ed.; Kiepenheuer \& Witsch: Köln, Germany, 1969; pp. 108-123.

23. Dahrendorf, R. Pfade aus Utopia: Arbeiten zur Theorie und Methode der Soziologie; Piper: München, Germany, 1968. 
24. Kühne, O. Landscape Conflicts: A Theoretical Approach Based on the Three Worlds Theory of Karl Popper and the Conflict Theory of Ralf Dahrendorf, Illustrated by the Example of the Energy System Transformation in Germany. Sustain. Sci. Pract. Policy 2020, 12, 6772. [CrossRef]

25. Kühne, O.; Leonardi, L. Ralf Dahrendorf: Between Social Theory and Political Practice; Palgrave Macmillan: London, UK, 2020.

26. Kühne, O.; Berr, K.; Jenal, C.; Schuster, K. Liberty and Landscape: In Search of Life-Chances with Ralf Dahrendorf; Palgrave Macmillan: Basingstoke, UK, 2021.

27. Kühne, O.; Weber, F.; Berr, K. The productive potential and limits of landscape conflicts in light of Ralf Dahrendorf's conflict theory. Soc. Mutam. Politica 2019, 10, 77-90.

28. Kühne, O. Dahrendorf as champion of a liberal society-Border crossings between political practice and sociopolitical theory. Soc. Mutam. Politica 2019, 10, 37-50.

29. Gratzel, G.A. Freiheit, Konflikt und Wandel: Bemerkungen zum Liberalismus-Verständnis bei Ralf Dahrendorf. In Jahrbuch zur Liberalismus-Forschung: 2. Jahrgang 1990; Fleck, H.-G., Frölich, J., Padtberg, B.-C., Eds.; Nomos: Baden-Baden, Germany, 1990; pp. 11-45.

30. Leonardi, L. Introduzione a Dahrendorf; Editori Laterza: Roma, Italy; Bari, Italy, 2014; ISBN 8858110218.

31. Dahrendorf, R. Bildung ist Bürgerrecht: Plädoyer für Eine Aktive Bildungspolitik, Neuauflage; Christian Wegner: Hamburg, Germany, 1968.

32. Dahrendorf, R. Lebenschancen: Anläufe zur Sozialen und Politischen Theorie; Suhrkamp: Frankfurt, Germany, 1979 ; ISBN 3518370596.

33. Dahrendorf, R. Auf der Suche Nach Einer Neuen Ordnung: Vorlesungen zur Politik der Freiheit im 21. Jahrhundert, 4. Auflage; CH Beck: München, Germany, 2007.

34. Dahrendorf, R. Der Moderne Soziale Konflikt: Essay zur Politik der Freiheit; Dtv: München, Germany, 1994; ISBN 3-423-04628-7.

35. Bonacker, T. (Ed.) Konflikttheorien: Eine Sozialwissenschaftliche Einführung mit Quellen; Leske+Budrich: Leverkusen, Germany, 1996; ISBN 381001544X.

36. Dahrendorf, R. Soziale Klassen und Klassenkonflikt in der Industriellen Gesellschaft; Enke: Stuttgart, Germany, 1957.

37. Dahrendorf, R. Liberalism. In The New Palgrave Dictionary of Economics; Eatwell, J., Ed.; Macmillan: London, UK, 1991; pp. 385-389.

38. Dahrendorf, R. Aktive und passive Öffentlichkeit: Über Teilnahme und Initiative im politischen Prozeß moderner Gesellschaften. In Das Publikum; Löffler, M., Ed.; CH Beck: München, Germany, 1969; pp. 1-12.

39. Lipset, S.M.; Rokkan, S. (Eds.) Party Systems and Voter Alignments: Cross-National Perspectives; Free Press: New York, NY, USA, 1967.

40. Luhmann, N. Systemtheorie der Gesellschaft; Suhrkamp: Berlin, Germany, 2017; ISBN 9783518587058.

41. Bauman, Z. Life in Fragments: Essays in Postmodern Morality; Blackwell Publishers: Oxford, UK, 1995 ; ISBN 0631192670.

42. Subramanian, S. The Deep Conspiracy Roots of Europe's Strange Wave of Cell-Tower Fires. Available online: https:// www.politico.com/news/magazine/2020/05/18/deep-conspiracy-roots-europe-wave-cell-tower-fires-264997 (accessed on 19 July 2021).

43. Bourdieu, P. Ökonomisches Kapital, kulturelles Kapital, soziales Kapital. In Handbuch Bildungs—und Erziehungssoziologie; Bauer, U., Bittlingmayer, U.H., Scherr, A., Eds.; Springer VS: Wiesbaden, Germany, 2012; pp. 228-242.

44. Vetter, A.; Remmer-Bollow, U. Bürger und Beteiligung in der Demokratie: Eine Einführung; Springer Fachmedien: Wiesbaden, Germany, 2017.

45. Stark, T. Demokratische Bürgerbeteiligung Außerhalb des Wahllokals: Umbrüche in der Politischen Partizipation Seit den 1970er-Jahren; Springer Fachmedien Wiesbaden: Wiesbaden, Germany, 2019.

46. Weßels, B. Politische Ungleichheit beim Wählen. In Demokratie und Krise: Zum Schwierigen Verhältnis von Theorie und Empirie; Merkel, W., Ed.; Springer VS: Wiesbaden, Germany, 2015; pp. 67-94, ISBN 978-3-658-05945-3.

47. Schlozman, K.L.; Brady, H.E.; Verba, S. Unequal and Unrepresented: Political Inequality and the People's Voice in the New Gilded Age; Princeton University Press: Princeton, NJ, USA, 2018.

48. Neumann, K.-H.; Queder, F.; Hausner, K.H.; Schäfer, D.; Lohmann, S. Mobilfunknetze: Erfolgsvoraussetzungen für 5G. Wirtsch.-Z. Wirtsch. 2019, 99, 84-86. [CrossRef]

49. Nett, L.; Sörries, B. Infrastruktur-Sharing und 5G: Anforderungen an Regulierung, Neue Wettbewerbliche Konstellationen. Available online: https:/ / www.econstor.eu/bitstream/10419/227054/1/WIK-Diskussionsbeitrag-Nr-443.pdf (accessed on 3 May 2021).

50. Grotepass, J.; Eichinger, J.; Voigtländer, F. Mit 5G zu neuen Potentialen in Produktion und Logistik. In Handbuch Industrie 4.0: Band 3: Logistik, 3. Auflage; Hompel, M.t., Bauernhansl, T., Vogel-Heuser, B., Eds.; Springer Vieweg: Berlin/Heidelberg, Germany, 2020; pp. 251-284, ISBN 978-3-662-58530-6.

51. Al-Falahy, N.; Alani, O.Y. Technologies for 5G Networks: Challenges and Opportunities. IT Prof. 2017, 19, 12-20. [CrossRef]

52. Boccardi, F.; Heath, R.W.; Lozano, A.; Marzetta, T.L.; Popovski, P. Five disruptive technology directions for 5G. IEEE Commun. Mag. 2014, 52, 74-80. [CrossRef]

53. Eldred, C.; Kenney, M.; Kushida, K.E.; Murray, J.; Zysman, J. 5G: Revolution or Hype? Available online: https:/ / papers.ssrn. com/sol3/papers.cfm?abstract_id=3443740 (accessed on 29 April 2021).

54. Umweltinstitut München e. V. Mobilfunk Strahlung. Elektrosmog: Wie Kann Ich Vorsorgen? Available online: http://www. umweltinstitut.org/fileadmin/Mediapool/Druckprodukte/Mobilfunk/PDF/Broschuere_Mobilfunkstrahlung_web.pdf (accessed on 15 May 2015). 
55. Hutter, H.-P.; Moshammer, H.; Wallner, P.; Kundi, M. Public perception of risk concerning celltowers and mobile phones. Soz. Praventivmed. 2004, 49, 62-66. [CrossRef]

56. Siegrist, M.; Earle, T.C.; Gutscher, H.; Keller, C. Perception of mobile phone and base station risks. Risk Anal. 2005, 25, 1253-1264. [CrossRef]

57. Jung, Y.; Kim, S. Response to potential information technology risk: Users' valuation of electromagnetic field from mobile phones. Telemat. Inform. 2015, 32, 57-66. [CrossRef]

58. Pauly, B.; Kriegeskotte, N. Bitkom Präsentiert Studie zur Akzeptanz von Mobilfunkmasten. Available online: https://www. bitkom.org/Presse/Presseinformation/Studie-zur-Akzeptanz-von-Mobilfunkmasten (accessed on 27 April 2021).

59. Bonus. Röstigraben und 5G. Available online: https://www.bonus.ch/Pdf/2020/Mobilfunktelefonie-5G.pdf (accessed on 27 April 2021).

60. Statista. Was ist der Hauptgrund, aus dem Sie Gegen 5G Sind?: Umfrage zu Gründen für die Ablehnung der Einführung von 5G in der Schweiz 2020. Available online: https:/ / de.statista.com/statistik/daten/studie/1107174/umfrage/umfrage-zu-gruendenfuer-die-ablehnung-der-einfuehrung-von-5g-in-der-schweiz/ (accessed on 27 April 2021).

61. Just, C. 5G Bei der Telekom: 5G-Ausbau Geht Schneller Als Erwartet. Available online: https://www.computerbild.de/artikel/ cb-News-Handy-Telekom-5G-Netzausbau-Staedte-Frequenzen-29970117.html (accessed on 19 July 2021).

62. Telekom. Telekom Mobilfunk-Netzausbau. Available online: https://www.telekom.de/netz/mobilfunk-netzausbau (accessed on 19 July 2021).

63. Vodafone. Netzabdeckung: So Gut ist Unser Netz: Unsere Netzkarte für Ganz Deutschland. Available online: https://www. vodafone.de/hilfe/netzabdeckung.html (accessed on 19 July 2021).

64. Weber, F.; Jenal, C.; Roßmeier, A.; Kühne, O. Conflicts around Germany's Energiewende: Discourse patterns of citizens' initiatives. Quaest. Geogr. 2017, 36, 117-130. [CrossRef]

65. Walter, F.; Marg, S.; Geiges, L.; Butzlaff, F. (Eds.) Die Neue Macht der Bürger: Was Motiviert die Protestbewegungen? Rowohlt: Reinbek bei Hamburg, Germany, 2013; ISBN 9783498072544.

66. Gailing, L.; Naumann, M. Using focus groups to study energy transitions: Researching or producing new social realities? Energy Res. Soc. Sci. 2018, 455, 355-362. [CrossRef]

67. Berr, K.; Jenal, C.; Kühne, O.; Weber, F. Landschaftsgovernance: Ein Überblick zu Theorie und Praxis; Springer VS: Wiesbaden, Germany, 2019.

68. Kühne, O. Vom ,Bösen' und ,Guten' in der Landschaft-Das Problem moralischer Kommunikation im Umgang mit Landschaft und ihren Konflikten. In Landschaftskonflikte; Berr, K., Jenal, C., Eds.; Springer VS: Wiesbaden, Germany, 2019; pp. 131-142.

69. Kühne, O. Die Moralisierung von Landschaft-Überlegungen zu einer problematischen Kommunikation aus Sicht der Luhmannschen Systemtheorie. In Diedrich Bruns Wird Gelehrt Haben: Eine Festschrift; Hennecke, S., Kegler, H., Klaczynski, K., Münderlein, D., Eds.; Kassel University Press: Kassel, Germany, 2018; pp. 115-121, ISBN 9783737650649.

70. Berr, K.; Kühne, O. Moral und Ethik von Landschaft. In Handbuch Landschaft; Kühne, O., Weber, F., Berr, K., Jenal, C., Eds.; Springer VS: Wiesbaden, Germany, 2019; pp. 351-365.

71. Weber, F.; Kühne, O.; Jenal, C.; Sanio, T.; Langer, K.; Igel, M. Analyse des Öffentlichen Diskurses zu Gesundheitlichen Auswirkungen von Hochspannungsleitungen-Handlungsempfehlungen für die Strahlenschutzbezogene Kommunikation Beim Stromnetzausbau: Ressortforschungsbericht. Available online: https://doris.bfs.de/jspui/bitstream/urn:nbn:de:0221-2016050414038/3 /BfS_2016_3614S80008.pdf (accessed on 31 August 2020).

72. Chi, N. LED-Based Visible Light Communications; Tsinghua University Press: Berlin, Germany; Beijing, China, 2018; ISBN 3662566583.

73. Ghassemlooy, Z.; Alves, L.N.; Zvánovec, S.; Khalighi, M.-A. Visible Light Communications: Theory and Applications; CRC Taylor \& Francis Group: Boca Raton, FL, USA, 2017; ISBN 9781498767538.

74. Wang, Z.; Wang, Q.; Huang, W.; Xu, Z. Visible Light Communications: Modulation and Signal Processing; John Wiley \& Sons Incorporated: Newark, NJ, USA, 2017; ISBN 9781119331841.

75. Arbeitskreis Elektrobiologie, e.V. Alternativen. Available online: https://www.elektrobiologie.org/alternativen/ (accessed on 9 September 2021).

76. Elektro-sensibel. Prävention-Gesundheitsvorsorge: (Re-)Vitalisierung \& Eigenverantwortung. Available online: http:/ /www. elektro-sensibel.de/gesundheitsvorsorge.php (accessed on 9 September 2021).

77. Elektrosensibel-Muenchen. Reduzierung von Elektromagnetischen Feldern. Available online: https://www.elektrosensibelmuenchen.de/reduzierung-von-elektromagnetischen-feldern.html (accessed on 9 September 2021).

78. Risiko 5G. Willkommen: Neue Technologien Bergen auch Risiken. Available online: https://www.risiko-5g-ig.info/ (accessed on 9 September 2021).

79. Diagnose: Funk. Technik Sinnvoll Nutzen. Available online: https://www.diagnose-funk.org/ (accessed on 9 September 2021).

80. Gesundes 5-Seen-Land. Wir Lieben Unser 5-Seen-Land. Available online: https://www.gesundes-5-seen-land.de/ (accessed on 9 September 2021).

81. Bourdieu, P. Distinction: A Social Critique of the Judgement of Taste; Harvard University Press: Cambridge, MA, USA, 1984; ISBN 0674212800.

82. Weber, F.; Kühne, O.; Jenal, C.; Aschenbrand, E.; Artuković, A. Sand im Getriebe: Aushandlungsprozesse um die Gewinnung Mineralischer Rohstoffe aus Konflikttheoretischer Perspektive Nach Ralf Dahrendorf; Springer VS: Wiesbaden, Germany, 2018. 
83. Moor, J.D.; Uba, K.; Wahlström, M.; Wenngerhag, M.; De Vydt, M.; Wennerhag, M.; de Vydt, M.; Almeida, P.; Baukloh, A.; Bertuzzi, N.; et al. (Eds.) Protest for a Future II: Composition, Mobilization and Motives of the Participants in Fridays For Future Climate Protests on 20-27 September, 2019, in 19 Cities around the World; Open Science Framework: 2020. Available online: https://www.google.com/url?sa=t\&rct=j\&q=\&esrc=s\&source=web\&cd=\&ved=2ahUKEwjTzeSWi9H0 AhXnRPEDHRXcAiIQFnoECAUQAQ\&url=https\%3A\%2F\%2Fosf.io\%2F3hcxs\%2Fdownload\&usg=AOvVaw1t7fJAZzS5FS9 DMKnH8MZH (accessed on 5 December 2021).

84. Wahlström, M.; Kocyba, P.; De Vydt, M.; Moor, J.D. (Eds.) Protest for a Future: Composition, Mobilization and Motives of the Participants. In Fridays For Future Climate Protests on 15 March, 2019 in 13 European Cities; Online-Ausgabe: Berlin, Germany, 2019.

85. Diagnose: Funk. Widerstands-Und Vernetzungskarte. Available online: https://www.diagnose-funk.org/aktivitaeten/karte (accessed on 15 June 2021).

86. Landatlas. Daten-Download Landatlas. Available online: https://www.landatlas.de/daten.html (accessed on 18 August 2021).

87. Statistische Ämter des Bundes und der Länder. Bruttoinlandsprodukt, Bruttowertschöpfung (Kreise). Available online: https: //www.statistikportal.de/de/vgrdl/ergebnisse-kreisebene/bruttoinlandsprodukt-bruttowertschoepfung-kreise (accessed on 7 June 2021).

88. Radtke, J.; Renn, O. Partizipation und bürgerliche Engagement in der Energiewende. In Energiewende: Eine Sozialwissenschaftliche Einführung; Radtke, J., Canzler, W., Eds.; Springer VS: Wiesbaden, Germany, 2019; pp. 283-316.

89. Othengrafen, F. (Ed.) Städtische Planungskulturen im Spiegel von Konflikten, Protesten und Initiativen; Planungsrundschau Verl. Altrock: Berlin, Germany, 2015; ISBN 978-3-937735-15-3.

90. Zilles, J.; Schwarz, C. Bürgerproteste gegen Windkraft in Deutschland: Organisation und Handlungsstrategien. Informationen zur Raumentwicklung. Inf. Raumentwickl. 2015, 1, 669-679.

91. Kamlage, J.-H.; Drewing, E.; Reinermann, J.L.; de Vries, N.; Flores, M. Fighting fruitfully? Participation and conflict in the context of electricity grid extension in Germany. Util. Policy 2020, 64, 101022. [CrossRef]

92. Reusswig, F.; Braun, F.; Heger, I.; Ludewig, T.; Eichenauer, E.; Lass, W. Against the wind: Local opposition to the German Energiewende. Util. Policy 2016, 41, 214-227. [CrossRef]

93. Gailing, L.; Leibenath, M. Political landscapes between manifestations and democracy, identities and power. Landsc. Res. 2017, 42, 1-12. [CrossRef]

94. Kühne, O.; Koegst, L.; Zimmer, M.-L.; Schäffauer, G. “... Inconceivable, Unrealistic and Inhumane”: Internet Communication on the Flood Disaster in West Germany of July 2021 between Conspiracy Theories and Moralization-A Neopragmatic Explorative Study. Sustainability 2021, 13, 11427. [CrossRef]

95. Popper, K.R. The Open Society and Its Enemies; Routledge: Abingdon, UK, 2011; ISBN 9780415610216.

96. Dear, M. Understanding and Overcoming the NIMBY Syndrome. J. Am. Plan. Assoc. 1992, 58, 288-300. [CrossRef]

97. Haddad, M.A. NIMBY is Beautiful: How Local Environment Protests Are Changing the World. In NIMBY is Beautiful: Cases of Local Activism and Environmental Innovation Around the World; Hager, C., Haddad, M.A., Eds.; Berghahn Books: New York, NY, USA; Oxford, UK, 2015; pp. 200-212, ISBN 9781782386018.

98. Devine-Wright, P. Rethinking NIMBYism: The role of place attachment and place identity in explaining place-protective action. $J$. Community Appl. Soc. Psychol. 2009, 19, 426-441. [CrossRef]

99. Renn, O. Technikakzeptanz: Lehren und Rückschlüsse der Akzeptanzforschung für die Bewältigung des technischen Wandels. Tech.-Theor. Prax. 2005, 14, 29-38. [CrossRef]

100. Körner, S. Naturbilder und Heimatideale in Naturschutz und Freiraumplanung. In Projektionsfläche Natur: Zum Zusammenhang von Naturbildern und Gesellschaftlichen Verhältnissen; Fischer, L., Ed.; Hamburg University Press: Hamburg, Germany, 2004; pp. 77-103, ISBN 3-937816-01-1.

101. Körner, S. Landschaft und Raum im Heimat-und Naturschutz. In Strukturierung von Raum und Landschaft: Konzepte in Ökologie und der Theorie Gesellschaftlicher Naturverhältnisse; Weingarten, M., Ed.; Westfälisches Dampfboot: Münster, Germany, 2005; pp. 107-117, ISBN 9783896915801.

102. Marg, S.; Zilles, J.; Schwarz, C. “Das Maß ist voll!” Proteste gegen Windenergie. In Bürgerproteste in Zeiten der Energiewende: Lokale Konflikte um Windkraft, Stromtrassen und Fracking; Hoeft, C., Messinger-Zimmer, S., Zilles, J., Eds.; Transcript: Bielefeld, Germany, 2017; pp. 63-95.

103. Becker, S.; Naumann, M. Energiekonflikte erkennen und nutzen. In Bausteine der Energiewende; Kühne, O., Weber, F., Eds.; Springer VS: Wiesbaden, Germany, 2018; pp. 509-522, ISBN 978-3-658-19508-3.

104. Leibenath, M.; Otto, A. Competing Wind Energy Discourses, Contested Landscapes. Landsc. Online 2014, 38, 1-18. [CrossRef]

105. Eichenauer, E.; Reusswig, F.; Meyer-Ohlendorf, L.; Lass, W. Bürgerinitiativen gegen Windkraftanlagen und der Aufschwung rechtspopulistischer Bewegungen. In Bausteine der Energiewende; Kühne, O., Weber, F., Eds.; Springer VS: Wiesbaden, Germany, 2018; pp. 633-651, ISBN 978-3-658-19508-3. 